\title{
USE OF INTERLEUKIN 6 (IL-6) INHIBITORS CONCOMITANT WITH OCULAR INFECTION BY HERPES ZOSTER IN A PATIENT WITH RHEUMATOID ARTHRITIS.
}

Daniel Freire de Medeiros (UFPB, João Pessoa, PB, Brasil), Sanna Paula Pires Mariano Campos (UFPB, João Pessoa, PB, Brasil), Anna Luisa Marinho de Andrade (UFPB, João Pessoa, PB, Brasil), Ana Karla Guedes de Melo (UFPB, João Pessoa, PB, Brasil), Danielle Christinne Soares Egypto de Brito (UFPB, João Pessoa, PB, Brasil), Eutilia Andrade Medeiros Freire (UFPB, João Pessoa, PB, Brasil)

\section{BACKGROUND}

Rheumatoid Arthritis (RA) is a chronic inflammatory disease that results from the complex interaction between genetic and environmental factors, and is associated with a high risk of viral infection, especially during immunobiological use. Tocilizumab is effective in treating this disease by limiting the multiple proinflammatory activities of IL- 6 by inhibiting its gp130 receptor. Studies with mice deficient in IL- 6 demonstrated susceptibility to Herpes Zoster infection, since the presence of this cytokine is necessary for a good immune response after infection by the zoster virus.

\section{CASE REPORT}

A 56-year-old female patient diagnosed with rheumatoid arthritis 2 years ago and using tocilizumab for 8 months . In 2018, she developed ocular herpes zoster with decreased visual acuity. The medication for AR was suspended, evolving with significant worsening of the joint involvement, leading to high clinical indexes of inflammatory activity and important functional limitation. The possibility of concomitant use of tocilizumab with antiviral therapy was discussed with the infectology, since the patient had severe and disabling joint disease and localized viral infection.

\section{CONCLUSION}

This case report shows the need for efforts of the Rheumatology and Infectology experts in the study of the association of autoimmune diseases and opportunistic infections. The interdisciplinary therapeutic approach is necessary to offer a satisfactory follow-up to the patients, minimizing risks of serious infection and ogetting better quality of life and control of the underlying disease. 